Www.jmscr.igmpublication.org

Impact Factor (SJIF): 6.379

Index Copernicus Value: 79.54

ISSN (e)-2347-176x ISSN (p) 2455-0450

crossrefDOI: https://dx.doi.org/10.18535/jmscr/v6i9.129

\title{
Variant hemoglobin (Hb hope) may enhance glycosylated hemoglobin (HbA1c) results of cation exchange high performance liquid chromatography
}

\author{
Authors \\ AK Kapoor ${ }^{1}$, Rajesh Kumar Srivastava ${ }^{2}$ \\ ${ }^{1}$ Pathologist, Department of Pathology, B 171 Nirala Nagar, Lucknow, UP, India \\ ${ }^{2}$ Senior Technologist, Department of Pathology, B 171 Nirala Nagar, Lucknow, UP, India \\ Corresponding Author \\ Dr Ashok Kumar Kapoor \\ Department of Pathology, B 171, Nirala Nagar, Lucknow-226020, Uttar Pradesh, India \\ Email:drashokkapoor2016@gmail.com
}

\begin{abstract}
HbAlc estimation is routinely done in our lab by cation exchange high performance liquid chromatography (HPLC) method. During 2 year period, we estimated the EDTA venous blood samples of $\sim 5000$ patients. Surprisingly, in 2 patients abnormally raised HblAc values were detected which were not in line with blood glucose levels (abnormal separation). One of the patients gave HbAlc value of $19.9 \%$ which suggested coelution of an hemoglobin variant along with glycosylated hemoglobin. Later, capillary electrophoresis (CE) of the sample showed an abnormal minor peak of a variant Hb adjacent to HbA; its concentration was $1.2 \%$. Similarly, another patient also gave high Alc value of $21.2 \%$ by HPLC; CE electrophoregram of the sample showed a minor variant peak (1.4\%) abutting HbA. Hb variant appeared to alter the HbAlc result and later required correction using another method.

Keywords: Abnormal hemoglobins falsely interfere Alc results.
\end{abstract}

\section{Introduction}

Management of diabetes mellitus (DM) depends on accurate measurement of HbAlc. The level of HbA1c is 4 to $6 \%$ in healthy subjects without diabetes. We had 2 patients with uncontrolled DM with abnormally high values of HbA1c (19.9\% and $21.2 \%)$ by HPLC which appeared improbable. Later, CE electrophoregram of both EDTA blood samples showed minor peaks of an hemoglobin variant adjacent to major $\mathrm{HbA}$ peak. Herewith, we report 2 cases with heterozygous $\mathrm{Hb}$ variants which appeared to enhance the true value of HbA1c.

\section{Case Report}

One of our patients was a female, aged 57 years. She had fasting blood sugar of $502 \mathrm{mg} / \mathrm{dl}$. PP blood sugar after 2 hours of meals was $775 \mathrm{mg} / \mathrm{dl}$. In addition, she had asymptomatic mild microcytic anemia ( $\mathrm{Hb} 10.9 \mathrm{gm} / \mathrm{dl})$ with raised RBC count $\left(6.59\right.$ million $\left./ \mathrm{mm}^{3}\right)$. Processing of blood EDTA sample of this patient unexpectedly gave a raised value of HbA1c (19.9\%) which suggested overlapping with a variant hemoglobin (table 1). Later, CE electrophoregram of the same sample was done which showed a minor peak of a variant Hbas Z10 zone adjacent to $\mathrm{HbA}$ (figure 
1a). Another patient was a male, aged 36 years. He had fasting blood sugar level of $320 \mathrm{mg} / \mathrm{dl}$ and PP blood sugar 2 hours after meals was 560 $\mathrm{mg} / \mathrm{dl}$. A1c result by HPLC method gave a high value of $21.2 \%$; $\mathrm{Hb}$ variant value $\mathrm{CE}$ electro- phoregram was $1.4 \%$ (table 1). Processing of samples from both the patients by HPLC method showed interference by an $\mathrm{Hb}$ variant (figure 1); both $\mathrm{Hb}$ variant and $\mathrm{HbA1c}$ eluted in the same window leading to overestimation.

Table 1 : HPLC and capillary electrophoresis findings of two patients

\begin{tabular}{|l|c|c|c|c|}
\hline Lab ID & $\begin{array}{c}\text { Age in years/ } \\
\text { Gender }\end{array}$ & $\begin{array}{c}\text { HbA1c result } \\
\text { by HPLC }(\%)\end{array}$ & $\begin{array}{c}\text { Hemoglobin hope } \\
\text { result by capillary } \\
\text { electrophoresis }(\%)\end{array}$ & $\begin{array}{c}\text { Corrected } \\
\text { A1c value }\end{array}$ \\
\hline 091803290020 & $57 / \mathrm{F}$ & 19.9 & 1.2 & 18.7 \\
\hline 100241 & $36 / \mathrm{M}$ & 21.2 & 1.4 & 19.8 \\
\hline
\end{tabular}

$\mathrm{M}=$ male, $\mathrm{F}=$ female
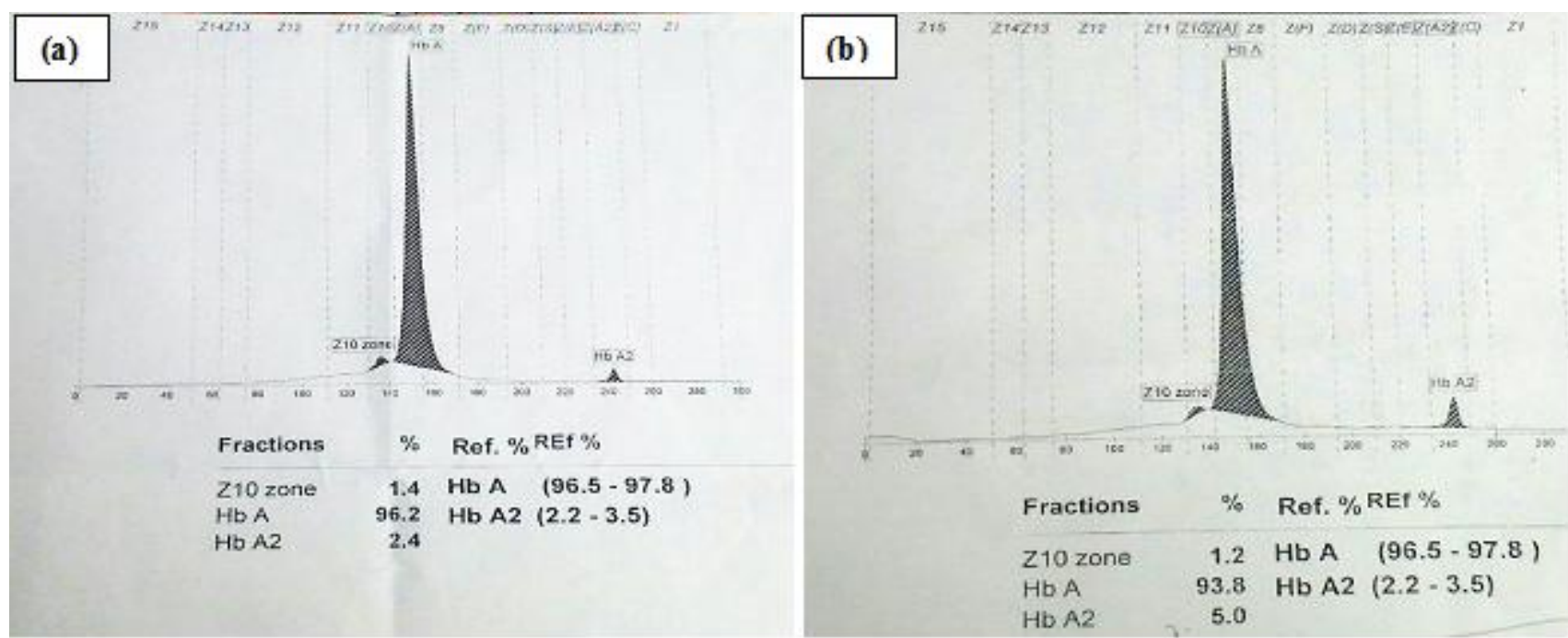

Graph showing a minor variant hemoglobin peak as Z10 zone on the capillary electrophoregram of (a) patient ID 091803290020 and (b) patient ID 100241.

\section{Discussion}

Electrophoresis depends upon charge differences on various hemoglobins. HPLC depends on the interchange of charged groups of the ionexchange material with charge groups on the $\mathrm{Hb}$ molecule $^{1}$. In current case report, HPLC gave falsely elevated $\mathrm{HbA1c}$ values which later required correction. Capillary electrophoresis at alkaline $\mathrm{pH} 9.4$ gave separate minor peak of $\mathrm{aHb}$ variant adjoining to major $\mathrm{HbA}$ peak. Several hemoglobin variants, e.g. $\mathrm{Hb}$ hope, $\mathrm{Hb}$ Novakchoff, Hb Wayne, HbIwale (M-Kankakee), Hbcanden (Tochuchi) may interfere with HbA1c and give spuriously raised result by HPLC method. Results of current report suggest that the possibility of abnormal $\mathrm{Hb}$ interfering with HbA1c peak should always be considered if it is not in line with blood glucose levels. Initial very high value of HbA1c by HPLC (>15\%) should always be evaluated by another method.

One of the hemoglobin variants ( $\mathrm{Hb}$ hope) was first described about 100 years ago ${ }^{2}$. Although $\mathrm{Hb}$ hope is clinically silent, it can impair tissue oxygen delivery ${ }^{3}$. Abnormal $\mathrm{Hb}$ variant has been reported in some families of African, Japanese and Thai origin ${ }^{4}$. Per test results using Bio-Rad D10 HPLC analyser, Hb hope and other variants coelute with HbA1c giving spurious results ${ }^{5}$. Therefore, the possibility of interference by a silent $\mathrm{Hb}$ like $\mathrm{Hb}$ hope should always be discussed while analyzing the abnormally raised $\mathrm{HbA} 1 \mathrm{c}$ value. Moreover, several methods for estimation of glycosylated $\mathrm{Hb}$ should be used while dealing with aberrant raised HbA1c value ${ }^{6}$. The laboratories should have alternative assay systems such as glycated albumin to assist the 
management of the DM patient with a hemoglobin variant. One of our patients had mild anemia which suggested the finding as heterozygous $\mathrm{Hb}$ variant. Abnormal hemoglobin neither caused alterations in RBCs nor produced symptoms, suggesting possibility of hemoglobin hope ${ }^{2}$ in our patients.

\section{Conclusion}

Physicians heavily depend on the results of HbA1c while managing a case with Diabetes mellitus. Very high HbA1c value was obtained by HPLC chromatogram which may be improbable. Later, the resultswere corrected using another method. Moreover, alternative tests, e.g. glycated albumin should be available. Further, new methods are being developed such as mass spectrometry and another method which requires quenching of the fluorescence of an eosin-boronic acid solution.

\section{Financial and competing interests: None}

\section{Acknowledgement}

We appreciate the support and help of Professor Dr. Sanjay Mehrotra.

\section{References}

1. Wild BJ, Bain BJ: Investigation of abnormal hemoglobins and thalassemia. In 'Dacie and Lewis Practical haematology. Lewis SM, Bain BJ, Bates I (editors), $\quad 9^{\text {th }} \quad$ edition, Churchill Livingstone, London, 2001, p 231-268.

2. Minnichi V, Hill RJ, Khuri PD, Anderson ME. Hemoglobin Hope : A beta chain variant. Blood 1965; 25 : 830-838.

3. Bibi A, Touhem I, Sahli $\mathrm{C}$ et al. Fortuitous description of hemoglobin Hope in a high-level Tunisianathlete: molecular diagnosis and origin - Ann BiolClin (Paris) 2012; 70 : 295-298.
4. Fellahi S, Henderson M, Capeau J, Bastard JP. Hemoglobin hope and glycated hemoglobin : One peak may or may not hide the other, depending on the assay. Diabetes metab 2012; 38(3) : 276-277.

5. Beneitez D, Carrera A, Ramon DuranSuarej J, Paz V, Leon A, Garcia Talavera J. Heterozygous Hbhope [ $\beta 136(\mathrm{H} 14)$ $\mathrm{Gly} \rightarrow$ Asp] in association with heterozygous $\beta$ o-thalassemia with apparent homozygous expression in a Spanish patient. Hemoglobin 2006; 30(1) : 45-49.

6. Singh B, Behera DD, Mehta Neelam, Das Seema.Hbhope: A rare variant of Haemoglobin - Forged a rise in HbA1c on immunoturbidimetric assay. Ind $\mathrm{J}$ Clin Biochem 2014; 29(4) : 517-519. 